\title{
Working
}

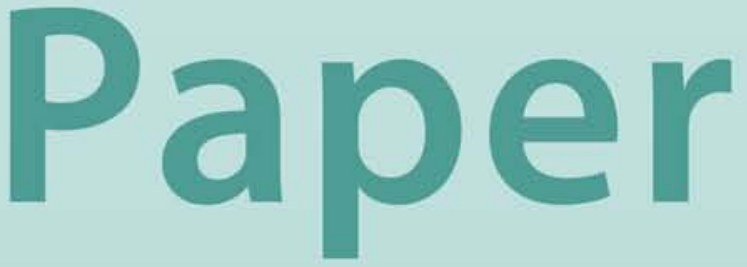




\title{
The Persistence of Capital Account Crises
}

\author{
Mauro Mecagni, Ruben Atoyan, David
}

Hofman 


\title{
IMF Working Paper
}

Strategy, Policy, and Review Department

\section{The Persistence of Capital Account Crises}

\section{Prepared by Mauro Mecagni, Ruben Atoyan, David Hofman ${ }^{1}$}

Authorized for distribution by Mauro Mecagni

May 2009

\begin{abstract}
This Working Paper Working Paper should not be reported as representing the views of the IMF.

The views expressed in this Working Paper are those of the author(s) and do not necessarily represent those of the IMF or IMF policy. Working Papers describe research in progress by the author(s) and are published to elicit comments and to further debate.
\end{abstract}

This study contributes to the literature on capital account crises in two ways. First, our analysis of crisis episodes between 1994 and 2002 establishes a clear relationship between the persistence of crises, their complexity, and the intensity of movement of key macroeconomic variables. Second, we provide a systematic examination of the determinants of crisis duration. Our econometric analysis suggests that initial conditions and the external environment plays a key role in determining crisis persistence. The policy response also matters, but cannot offset a record of poor past policies. Overall, the results underscore the critical importance of crisis prevention efforts.

JEL Classification Numbers: F32, F34, C41, C43

Keywords: capital account crises, persistence, balance sheets

Author’s E-Mail Address:mmecagni@imf.org, ratoyan@imf.org, dhofman@imf.org

\footnotetext{
${ }^{1}$ This study builds in part on the results of an earlier working paper (Mecagni, Atoyan, Hofman, and Tzanninis (2007)). The authors would like to thank Guillermo Calvo and Robert Flood for their encouragement and useful suggestions. All remaining errors are ours.
} 


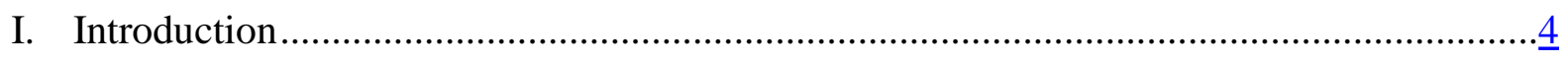

II. Conceptual Framework and Methodology....................................................................

A. Crisis Persistence, Complexity, and Macroeconomic Effects ………………………....

B. Determinants of the Duration of Crises ........................................................................

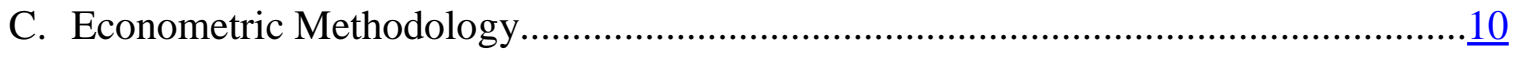

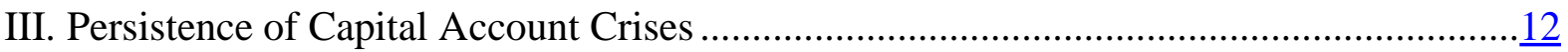

A. Estimation Results and Robustness Tests ...............................................................12

B. Counterfactual Experiments......................................................................................

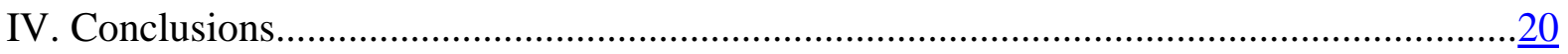

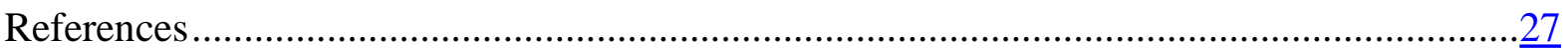

Boxes

1. Some Further Diagnostic Results.................................................................................

Figures

1. Average Duration and Crisis Complexity.........................................................................

2. Crisis Complexity, Duration, and Macroeconomic Costs ....................................................

3. Post-Crisis Vulnerabilities ...........................................................................................

4. Predicted Probabilities of Staying in Crisis under Different Scenarios ..............................18

5. Increase in Predicted Probability of Exit from Crisis under Various Scenarios...................19

6. Reduction in Predicted Crisis Duration under Various Scenarios .......................................19

\section{Tables}

1. Duration and Nature of Crises .....................................................................................

2. Estimation Results for the Capital Account Crises Duration Model ……………….......... $\frac{13}{17}$

3. Descriptive Statistics for the Model Variables ..................................................................

Appendices

1. Measuring the Duration of Capital Account Crises ...........................................................21

2. A Model for the Duration of Capital Account Crises ......................................................... 


\section{INTRODUCTION}

Capital account crises - episodes of financial distress characterized by abrupt capital outflows - tend to be highly disruptive and have deep macroeconomic and social consequences. They have posed major challenges to policymakers, making it important to gain a thorough understanding of these crises and their impact.

In their disruptive effects, capital account crises differ from earlier types of currency crises identified in the literature. ${ }^{2}$ These earlier episodes were typically associated with some inherent inconsistency between an exchange rate peg on the one hand and either expansive fiscal policies or an inability or unwillingness to bear the costs of defending the peg on the other. The resulting currency crisis forced an exit from the peg and a swift correction of the exchange rate that resolved the inconsistency. Such crises were usually short-lived and the economic costs were often relatively low. ${ }^{3}$

Capital account crises, however, are closely associated with balance sheet interlinkages between various sectors in an economy, which set the stage for an adverse chain reaction where initial distress in one sector is rapidly transmitted to others. Under such circumstances, a loss of confidence among investors and the resulting sharp outflow of capital—which may sometimes be triggered by unease about the existing balance sheet vulnerabilities themselves - can cause successive or simultaneous problems in multiple sectors of the economy, giving rise to so called "twin" or "triple" crises. ${ }^{4}$

Capital account crises, therefore, are not short-lived, self-correcting events. Rather, they are characterized by a progressive deepening of the crisis as initial problems work their way through the various sectors of the economy. In addition, the wider the reach of the crisis, the more likely it is that investors' pessimistic expectations become entrenched, adding to the vicious circle, and thereby prolonging the crisis. The more severe real repercussions aside, these characteristics thus also introduce an element of "duration" to a crisis. That is, "crisis" becomes a state of the economy that persists for some time. As the study will show, crisis duration is strongly correlated with complexity (i.e., the nature of crisis episodes). And both are highly correlated with the depth of crises (i.e., the impact on macroeconomic variables). In other words, the more complex the nature of a crisis is, the longer it takes to resolve it, and the more damaging its effects tend to be.

\footnotetext{
${ }^{2}$ See Roubini and Setser (2004) or Krugman (2001) for helpful overviews of the evolution of the crisis literature.

${ }^{3}$ Indeed, sometimes the real economic implications of crises were positive as the depreciation of the exchange rate improved competitiveness and the abandonment of the peg allowed for a more expansionary monetary policy.

${ }^{4}$ Simultaneous or subsequent pressures in several sectors of the economy are commonly referred to as "twin" crises (typically, balance of payments cum banking crises) or "triple” crises (i.e., situations where a country faces simultaneous currency, banking, and sovereign debt problems).
} 
The aspect of crisis duration — and the factors that determine the persistence of crises - has thus far received little attention. ${ }^{5}$ Indeed, most of the literature on capital account crises has focused on the causes of financial distress and "crisis triggers" and-to lesser extent-on the macroeconomic impact of capital account crises and the policy response. ${ }^{6}$ To make a start with the analysis of crisis duration, this study uses a data set covering 18 crisis episodes (starting with Turkey and Mexico in 1994, and ending with Uruguay's crisis in 2002) to examine the relationship between crisis duration, complexity, and depth, and to provide systematic evidence on the factors that influence the persistence of crises. A better understanding of these aspects could help crisis prevention and inform the design of crisis resolution policies.

\section{CONCEPTUAL FramewORK AND METHODOLOGY}

\section{A. Crisis Persistence, Complexity, and Macroeconomic Effects}

Measuring the duration of a crisis requires the identification of its beginning and end. We employ an index approach-originally developed in Mecagni et al (2007) — that associates crises with elevated pressures on the exchange rate and reserves, large capital outflows, and significant deviations from "normal” levels of spreads on sovereign bonds.

The application of the index methodology to data for 12 emerging market economies commonly recognized as having experienced capital account crises yields 18 crisis episodes and highlights the following points. ${ }^{8}$

- $\quad$ First, duration increases as the nature of crises becomes more complex (Figure 1). Such complexity arises mainly because balance sheet interlinkages can quickly transmit problems originating in one sector of the economy to others. The vast

\footnotetext{
${ }^{5}$ Ramakrishnan and Zalduendo (2006) are an exception. Their work includes estimates of duration for episodes of "market pressures."

${ }^{6}$ Several studies have highlighted global financial conditions—-such as liquidity and investor perceptions as key triggers of capital account crises. These studies tend to argue that prudent domestic policies are a necessary but not sufficient condition for protection from financial shocks (e.g., Calvo (1998) and Calvo (2005)). Another strand of literature emphasizes weaknesses in domestic balance sheets as a key cause of crises, and, sometimes, limited openness to trade (e.g., Ghosh (2006); Calvo, Izquierdo, and Mejia (2004), and Frankel and Cavallo (2004)). Countries' solvency and liquidity conditions are also identified as critical determinants of vulnerability to crises (e.g., Ramakrishnan and Zalduendo (2006); and Eichengreen, Gupta, and Mody (2006)). Studies that have focused on the macroeconomic impact of capital account crises and on policy responses typically find a large negative effect on output growth (Hutchison and Noy (2004); and Calvo, Izquierdo, and Talvi (2006)).

${ }^{7}$ Appendix I provides a brief description of the methodology employed to measure crisis duration along with some details on distribution of the crisis duration. See Mecagni et al (2007) for more details on the design of the index and its performance relative to alternative measures of crisis duration.

${ }^{8}$ In order to focus on known episodes of capital account crises, the sample considered was limited to 12 emerging market economies commonly cited in the literature on recent capital account crises: Argentina, Brazil, Ecuador, Indonesia, Korea, Malaysia, Mexico, Philippines, Russia, Thailand, Turkey, and Uruguay.
} 


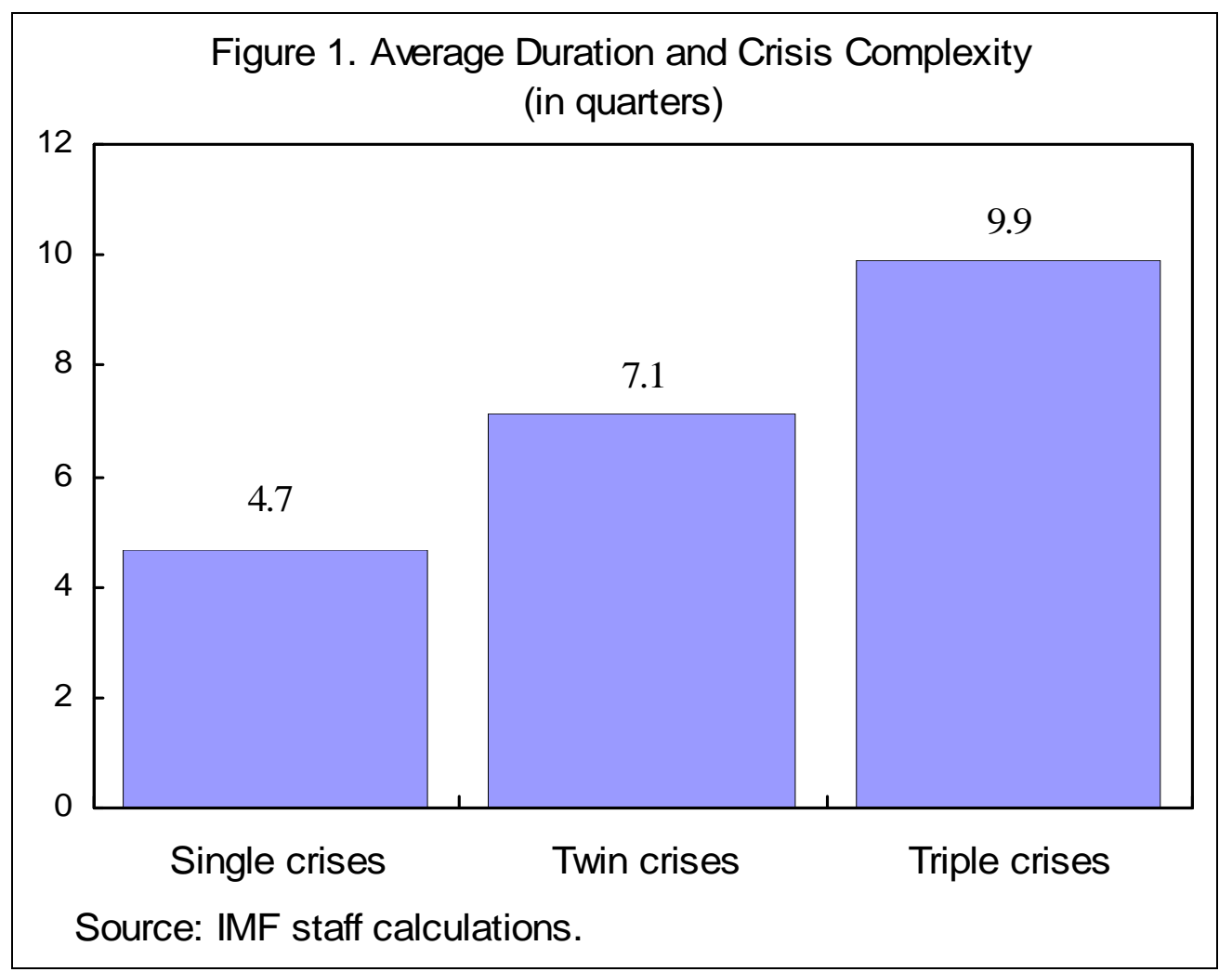

majority of crises in our sample (15 out of 18 crises) involved twin or triple crises (Table 1). And virtually all triple and half of the twin crises had longer-than-median duration. The three "single" crises were all shorter than the median duration.

- $\quad$ Second, duration and complexity of crises are directly linked to the severity of the macroeconomic impact. Longer and more complex crises have been associated with larger capital outflows and strikingly worse outcomes in terms of output loss and inflation (Figure 2). 
Table 1. Duration and Nature of Crises 1/

\begin{tabular}{|c|c|c|c|}
\hline \multirow[b]{2}{*}{ Duration } & \multicolumn{3}{|c|}{ Type of Crisis } \\
\hline & Single & Twin & Triple \\
\hline & \multicolumn{3}{|c|}{ (number of cases) } \\
\hline$\geq$ Median & 0 & 3 & 8 \\
\hline \multirow[t]{17}{*}{$<$ Median } & 3 & 3 & 1 \\
\hline & Turkey 1998 & Turkey 1994 & Mexico 1994 \\
\hline & & (C, B) & (C, D, B) \\
\hline & Philippines 2000 & Argentina 1995 & Indonesia 1997 \\
\hline & & (D, B) & $(\mathrm{C}, \mathrm{D}, \mathrm{B})$ \\
\hline & $\begin{array}{l}\text { Philippines } 2002 \\
\text { (B) }\end{array}$ & $\begin{array}{l}\text { Malaysia } 1997 \\
\quad(\mathrm{C}, \mathrm{B})\end{array}$ & $\begin{array}{c}\text { Korea } 1997 \\
(\mathrm{C}, \mathrm{D}, \mathrm{B})\end{array}$ \\
\hline & & Philippines 1997 & Brazil 1998 \\
\hline & & Thailand 1997 & Russia 1998 \\
\hline & & $(\mathrm{C}, \mathrm{B})$ & $(C, D, B)$ \\
\hline & & Brazil 2002 & Ecuador 1999 \\
\hline & & $(C, D)$ & $(\mathrm{C}, \mathrm{D}, \mathrm{B})$ \\
\hline & & & Turkey 2001 \\
\hline & & & $(\mathrm{C}, \mathrm{D}, \mathrm{B})$ \\
\hline & & & Argentina 2001 \\
\hline & & & $(\mathrm{C}, \mathrm{D}, \mathrm{B})$ \\
\hline & & & Uruguay 2002 \\
\hline & & & $(\mathrm{C}, \mathrm{D}, \mathrm{B})$ \\
\hline
\end{tabular}

Source: Staff calculations and assessments.

1/ C: currency crisis; D: debt crisis; and B: banking crisis. Classifications are based on listings by Kaminsky and Reinhart (1999) for twin crises, Kaminsky (2003) for currency crises,

Demirguc-Kunt and Detragiache (2005) and Caprio and Klingebiel (2003) for banking crises, and Manasse and others (2003) for sovereign debt crises, complemented with staff assessments for the most recent crisis episodes.

2/ In 1998, Turkey experienced large capital outflows, triggered by the Russian crisis. These outflows were not accompanied by currency, banking, or debt distress in Turkey at that time. 
Figure 2. Crisis Complexity, Duration, and Macroeconomic Costs
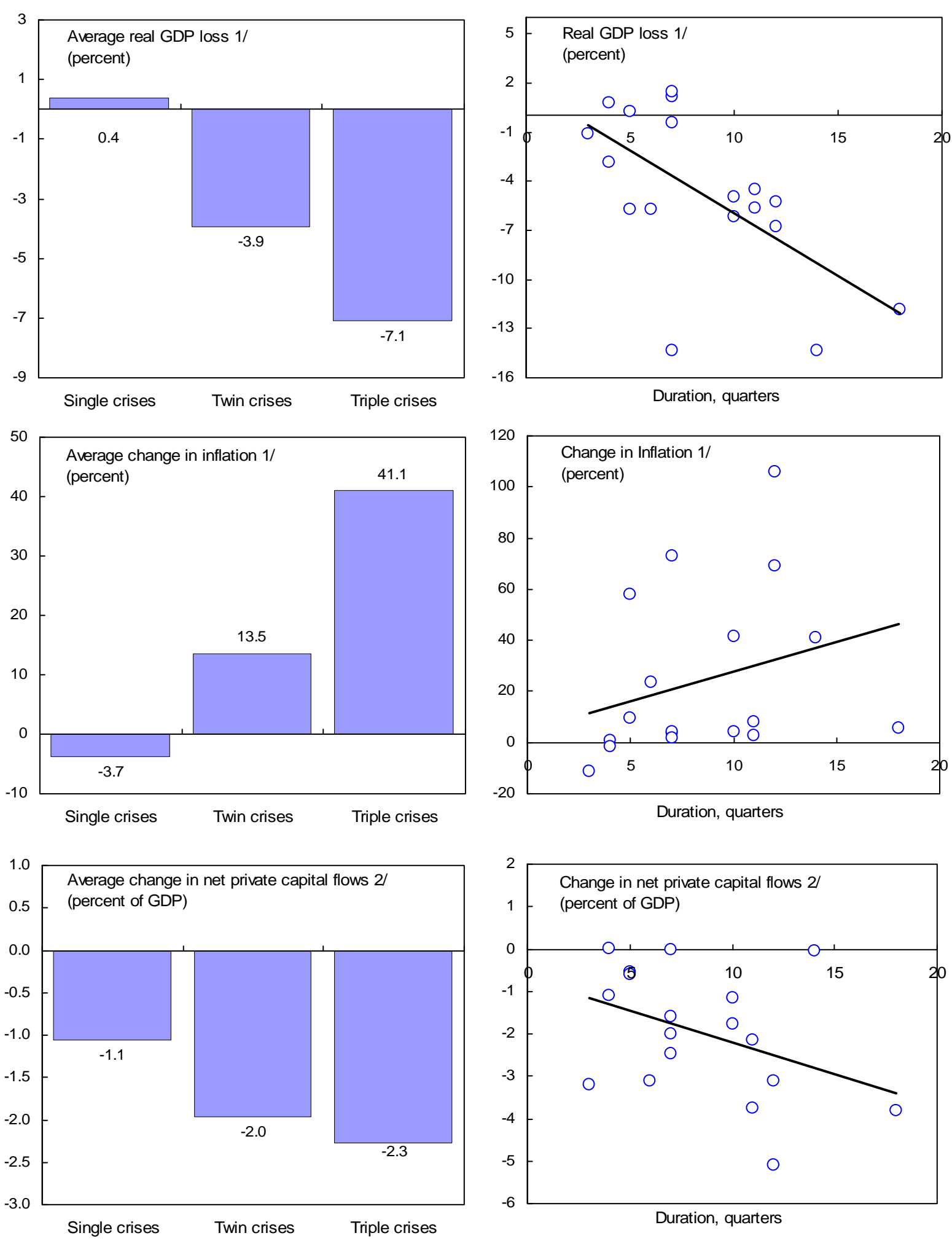

Source: IMF staff calculations

1/ Difference between the lowest/highest quarterly value during the crisis and the four-quarter averages preceding the crisis. 2/ Difference between the crisis average and the four-quarter averages preceding the crisis. 
- $\quad$ Third, more complex crises also carry greater post-crises debt-related vulnerabilities. Indeed, gross external debt ratios increased considerably in twin and triple crises (Figure 3). These increases reflect the effect of the exchange rate depreciation on the domestic-currency value of foreign-currency denominated debt and, in some cases, the deterioration of the fiscal position and the realization of contingent liabilities.

Figure 3. Post-Crisis Vulnerabilities

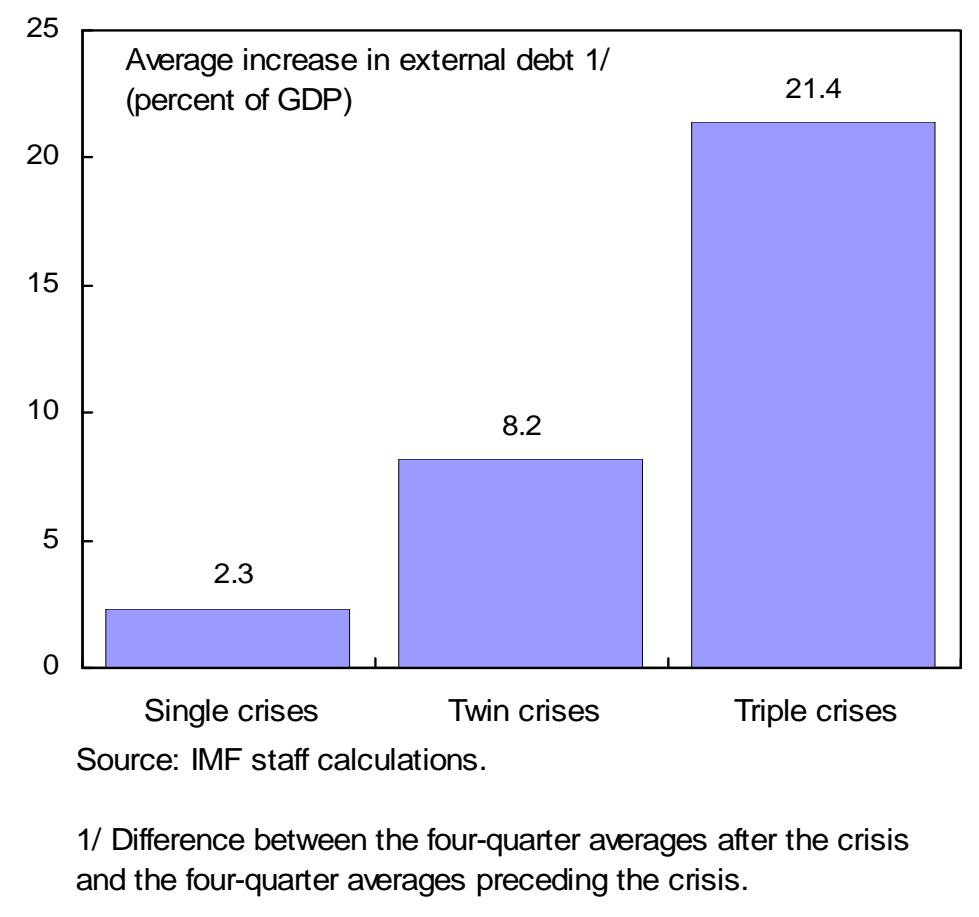

\section{B. Determinants Of The Duration Of Crises}

Notwithstanding the stylized facts highlighted above, large differences in duration, even between crises of similar typology, beg the question of whether it is possible to identify more systematically the specific factors that influence the persistence of the state of crisis. Conceptually, these factors can be broadly divided into four categories. ${ }^{9}$

- Initial conditions: A country's policy record and initial conditions are likely to have a bearing on the nature, the duration, and the depth of a crisis. For instance, large external imbalances, pre-existing solvency or liquidity risks, and balance sheet vulnerabilities are likely to affect policy options and market reactions, influencing the speed of crisis resolution.

\footnotetext{
${ }^{9}$ These categories are similar to those that may be used to examine the likelihood of entering into a crisis (see Ramakrisnan and Zalduendo (2006)). However, the considerations relevant to the probability of remaining or exiting a crisis (once the latter occurs) are quite different. See the discussion below.
} 
- $\quad$ External conditions: The pace of restoration of market confidence and the speed of economic recovery - and thus the length of a crisis - are likely to be influenced by external factors, including investors' appetite for emerging market assets, global liquidity conditions, the dynamics of terms of trade, and changes in export markets.

- $\quad$ Policy response: The authorities’ policy response can be expected to have a considerable impact on crisis duration, even if the interplay between certain policies and the evolution of a crisis is not always straightforward. For instance, fiscal adjustment will be essential to re-establish credibility in crises that are triggered by unsustainable fiscal positions. But it can also have adverse concretionary effects. Similarly, hikes in short-term interest rates may be critical to stem capital outflows, but can also have adverse effects on the real economy and domestic banks. And a move toward more exchange rate flexibility, unavoidable as it may be when foreign exchange reserves are running out, may have complex adverse effects on government, corporate, and financial sector balance sheets, particularly in cases of widespread currency substitution and currency mismatches. ${ }^{10}$

- IMF financial support. The availability, extent, and timing of official financing, particularly from the Fund, may also be key to the speed of recovery from crises driven by a sudden stop or exit of private capital. The presence of an IMF-supported program may signal the formulation of a comprehensive policy adjustment packagewhich could serve as a catalyst for private or official flows - and the provision of financial resources supporting the implementation of corrective measures. ${ }^{11}$

\section{Econometric Methodology}

The relative impact of the above determinants is estimated within the framework of a grouped duration model - a class of duration models typically used for panel-like data. ${ }^{12}$ Our dataset covers the 18 crisis episodes with a binary indicator that denotes the exit from crisis. The model assumes that the probability of exiting a crisis in each period (the dependent variable) is a function of two components: the time already spent in crisis (a time-dependent

\footnotetext{
${ }^{10}$ Structural policies are also likely to be important in determining the duration of a capital account crisis. However, the difficulty of quantifying these policies in a consistent format limits the scope of their inclusion in our econometric analysis.

${ }^{11}$ IMF-supported programs were in place in 15 out of the 18 crises in the sample. There were no programs (at the time) in Malaysia (1997), Philippines (2002), and Turkey (1998).

${ }^{12}$ Appendix II provides details on our application of survival analysis to studying durational aspects of capital account crises.
} 
baseline probability, $\lambda_{0}$, common to all crisis episodes) and a set of time-varying and countryspecific explanatory variables, $X:{ }^{13}$

$$
p[t, X(t) \mid \beta, u]=1-\exp \left[-\exp \left(\lambda_{0}(t)+X \beta+u\right)\right]
$$

Because empirical results can be sensitive to the specific functional form of the time dependent component, three alternative specifications are used to test the robustness of results. In line with specifications commonly used in the literature, we consider both logistic and linear time-dependent functional forms, as well as a simpler specification with no time variable, implying a time-invariant baseline probability of exiting the crisis:

$$
\lambda_{0}=\left\{\begin{array}{l}
\alpha_{0}+\alpha_{1} \ln (t), \\
\alpha_{0}+\alpha_{1} t, \\
\alpha_{0} .
\end{array}\right.
$$

The modeling exercise involves a general-to-specific specification search. The initial, general specification covers a range of variables capturing the complexity and lags in the effects of policy channels.

- With respect to initial conditions, the model controls for the pre-crisis levels of external debt (in percent of GDP) and short-term debt (in percent of reserves), along with their one-period lagged values, and for the pre-crisis primary fiscal balance and public debt-to-GDP ratio. ${ }^{14}$

- $\quad$ External conditions are proxied by the ratio to GDP of net private capital flows into emerging markets (as a measure of investor's appetite for emerging market countries' assets), the three-month LIBOR rate (as indicator of global liquidity conditions), and changes in the terms of trade and trade-weighted partner-countries' demand.

- In terms of policy response channels, the model includes changes in the primary fiscal balance (in percent of GDP) over a four-quarter period (contemporaneous and up to two lags), the policy interest rate differentials (vis-à-vis LIBOR) adjusted for the inflation differential with the United States (contemporaneous and up to six lags), and the exchange rate regime (based on the Fund's AREAER classification). ${ }^{15}$

\footnotetext{
${ }^{13}$ While the estimates are potentially subject to endogeneity bias (because exiting from crisis and certain policy options may be jointly determined), there is no selection bias since the sample includes only crisis observations, starting from the first quarter in crisis and ending with the exit quarter.

${ }^{14}$ Data availability prevents the inclusion of household, corporate, and banking sector balance sheet indicators.

${ }^{15}$ The AREAER classification ranks the various types of exchange rate regimes in eight categories, with higher values indicating a more flexible regime.
} 
- $\quad$ IMF financial support is represented by a measure of cumulative disbursements (in percent of GDP), interacting with an IMF program dummy. ${ }^{16,17}$

Starting from the general model, a specification search is conducted with a view to strike a balance between parsimony and performance of the model. The reduced form specifications were obtained by a sequential elimination of the least significant variables (or equivalently those with the highest p-value), which were identified on the basis of the Bayesian and Akaike information criteria.

\section{Persistence of Capital Account Crises}

\section{A. Estimation Results and Robustness Tests}

The estimation results for each of the model specifications are shown in Table 2. For both the logistic and linear time dependency specifications, the general-to-specific approach yields specifications (regressions $2 \mathrm{~b}$ and $3 \mathrm{~b}$, respectively) that include as explanatory variables external debt (with a one-quarter lag); the pre-crisis current account balance; capital flows to emerging market countries; the three-month LIBOR rate; the change in trade-weighted partner country demand; the change in the primary balance (with a one-quarter lag); and the real interest rate differential (with two and three-quarter lags). The exchange rate variable falls just short of being significant here and is therefore not included. ${ }^{18}$

Some of our results are sensitive to the specification of the functional form for the time dependency component. Exclusion of the time variable from the model results in a similar specification, but with the exchange rate regime and IMF financial support variables turning highly significant (regression 4). This result likely reflects the reduction of collinearity problems associated with the inclusion of the time variable. ${ }^{19}$ Because there are reasons to

\footnotetext{
${ }^{16}$ Similar results are obtained when cumulative IMF financing is normalized by the level of countries' short-term external debt.

17 The inclusion of the (contemporaneous) IMF variable in the model is likely subject to an endogeneity problem, since the extent of the Fund's financial involvement is likely to be correlated with the perceived severity of a crisis. To mitigate this problem, this variable is instrumented by the country's IMF quota, lagged debt-to-GDP ratio, lagged short-term debt-to-reserves ratio, lagged current account balance in percent of GDP, real GDP growth, and a variable capturing the time spent in crisis (log of time in crisis). Because the severity of a crisis is likely to influence the size of the IMF financial package, the value of the IKAC index (lagged two quarters) is also included as an instrument. While the estimation results are robust to the choice of lag, the second lag yields the highest likelihood value.

${ }^{18}$ In the specifications with time dependency, the exchange rate regime has p-values of 0.13 and 0.17 in regressions $2 \mathrm{a}$ and $3 \mathrm{a}$, respectively.

${ }^{19}$ By construction, the cumulative IMF financing variable increases with time. Similarly, a shift toward greater exchange rate flexibility (higher indices denote more flexible exchange rate regimes) is also likely to display some correlation with the time variable. These features are likely to introduce multicollinearity in specifications that include the time variable component of the hazard function.
} 
Table 2. Estimation Results for Capital Account Crises Duration Model

\begin{tabular}{|c|c|c|c|c|c|c|}
\hline \multirow{4}{*}{$\begin{array}{l}\text { Dependent variable: } \\
\text { Crisis Exit = 1-crisis ended, 0-still in crisis } \\
\text { Regression } \\
\text { Time dependence in baseline hazard }\end{array}$} & \multicolumn{6}{|c|}{ Regression 1/ } \\
\hline & \multirow{2}{*}{$\begin{array}{c}\text { General specification } \\
(1) \\
\end{array}$} & \multicolumn{5}{|c|}{ More parsimonious specifications } \\
\hline & & $(2 a)$ & $(2 b)$ & $(3 a)$ & $(3 b)$ & $(4)$ \\
\hline & $\lambda_{0}=\alpha_{0}+\alpha_{1} \ln (t)$ & \multicolumn{2}{|c|}{$\lambda_{0}=\alpha_{0}+\alpha_{1} \ln (t)$} & \multicolumn{2}{|c|}{$\lambda_{0}=\alpha_{0}+\alpha_{1} t$} & $\lambda_{0}=\alpha_{0}$ \\
\hline \multicolumn{7}{|l|}{ Baseline hazard } \\
\hline Quarters in crisis (log) & $2.719^{\star \star}$ & $2.680^{\star \star \star}$ & $2.501^{\star \star \star}$ & $\ldots$ & $\ldots$ & $\ldots$ \\
\hline Quarters in crisis & $\ldots$ & $\ldots$ & $\ldots$ & $0.353^{\star \star \star}$ & $0.342^{\star \star \star}$ & $\ldots$ \\
\hline Constant & -5.100 & -0.171 & $-2.671^{*}$ & 1.430 & -1.059 & $4.491^{\star \star}$ \\
\hline \multicolumn{7}{|l|}{ Initial conditions } \\
\hline External debt (pre-crisis) 2/ & 0.044 & $\ldots$ & $\ldots$ & $\ldots$ & $\ldots$ & $\ldots$ \\
\hline External debt (lag 1) 2/ & -0.058 & $-0.051^{\star}$ & $-0.039 \star \star$ & $-0.049^{*}$ & $-0.036^{\star \star}$ & $-0.042^{\star \star \star}$ \\
\hline Short-term debt (pre-crisis) 3/ & $0.008^{*}$ & $\ldots$ & $\ldots$ & $\ldots$ & $\ldots$ & $\ldots$ \\
\hline Short-term debt (lag 1) 3/ & -0.007 & $\ldots$ & $\ldots$ & $\ldots$ & $\ldots$ & $-0.012^{\star \star}$ \\
\hline Current account balance (pre-crisis) 2/ & $0.214^{\star \star \star}$ & $0.280^{\star \star \star}$ & $0.239 * \star \star$ & $0.311^{\star \star \star}$ & 0.261 *** & $0.162^{\star *}$ \\
\hline Primary balance (pre-crisis) 2/ & -0.001 & $\ldots$ & $\ldots$ & $\ldots$ & $\ldots$ & $\ldots$ \\
\hline Public debt (pre-crisis) $2 /$ & 0.025 & $\cdots$ & $\ldots$ & $\ldots$ & $\ldots$ & \\
\hline \multicolumn{7}{|l|}{ External conditions } \\
\hline Capital flows to EM countries 4/ & $0.856^{*}$ & 0.481 & 0.542 & 0.440 & 0.575 & $\ldots$ \\
\hline World interest rate $5 /$ & $-0.373^{*}$ & $-0.636^{\star *}$ & $-0.577^{\star \star \star}$ & $-0.594^{\star *}$ & $-0.543^{\star \star \star}$ & $-0.510^{\star \star \star *}$ \\
\hline Terms of trade (change) & 0.036 & $\cdots$ & $\ldots$ & $\cdots$ & $\ldots$ & $\ldots$ \\
\hline Trade-weighted partner country demand (change) & $1.318^{*}$ & $0.985^{\star \star}$ & $1.165^{\star \star \star}$ & $1.282^{\star \star \star}$ & $1.354^{\star \star \star}$ & $1.159^{\star \star *}$ \\
\hline \multicolumn{7}{|l|}{ Policy response } \\
\hline Change in primary balance $2 / 6 /$ & 0.035 & $\ldots$ & $\ldots$ & $\ldots$ & $\ldots$ & $\ldots$ \\
\hline Change in primary balance (lag 1) 2/ 6/ & $0.174^{\star \star}$ & $0.092^{\star \star}$ & $0.083^{\star *}$ & $0.087^{*}$ & $0.082^{*}$ & $0.096^{\star * *}$ \\
\hline Change in primary balance (lag 2) $2 / 6 /$ & -0.029 & $\ldots$ & $\ldots$ & $\ldots$ & $\ldots$ & $\ldots$ \\
\hline Real interest rate differential $7 /$ & 0.027 & $\ldots$ & $\ldots$ & $\ldots$ & $\ldots$ & $\ldots$ \\
\hline Real interest rate differential (lag 1) 7/ & -0.012 & $\cdots$ & $\ldots$ & $\cdots$ & $\ldots$ & $\cdots$ \\
\hline Real interest rate differential (lag 2) $7 /$ & -0.050 & $-0.035^{\star \star}$ & -0.031 & $-0.036^{\star \star}$ & -0.032 & $-0.040^{\star *}$ \\
\hline Real interest rate differential (lag 3) 7/ & 0.029 & $0.038^{\star \star \star}$ & $0.032^{\star *}$ & $0.039 * \star \star$ & $0.035^{\star \star}$ & $0.044^{\star \star}$ \\
\hline Real interest rate differential (lag 4) 7/ & 0.035 & $\ldots$ & $\ldots$ & $\ldots$ & $\ldots$ & $\ldots$ \\
\hline Real interest rate differential (lag 5) 7/ & -0.023 & $\ldots$ & $\ldots$ & $\ldots$ & $\ldots$ & $\ldots$ \\
\hline Real interest rate differential (lag 6) 7/ & 0.016 & $\ldots$ & $\ldots$ & $\ldots$ & $\ldots$ & $\ldots$ \\
\hline Exchange rate regime 8 / & -0.370 & -0.298 & $\ldots$ & -0.277 & $\ldots$ & $-0.386^{\star \star}$ \\
\hline \multicolumn{7}{|l|}{ IMF financial support } \\
\hline IMF financing*program dummy 9/ & 0.080 & 0.052 & $\cdots$ & 0.075 & $\cdots$ & $0.272^{\star \star}$ \\
\hline Number of observations & 153 & 153 & 153 & 153 & 153 & 153 \\
\hline Log likelihood & -30.822 & -34.467 & -35.858 & -35.693 & -36.955 & -40.026 \\
\hline Akaike Information Criterion & 111.564 & 92.934 & 91.715 & 95.386 & 93.909 & 102.051 \\
\hline Bayesian Information Criterion & 187.405 & 129.299 & 122.020 & 131.751 & 124.214 & 135.386 \\
\hline
\end{tabular}

Source: IMF staff calculations.

Note: ${ }^{* \star},{ }^{* *}$, and * indicate significance at the 1 percent, 5 percent, and 10 percent levels of significance based on robust standard errors.

1/ Complementary log-log model with homogenous parameters across crisis episodes allowing for heterogeneity across crises produces almost identical parameter estimates and LR test strongly rejecting the presence of heterogeneity, assuming Gamma or normally distributions.

2/ In percent of GDP.

$3 /$ In percent of foreign exchange reserves.

4/ Total net private capital flows to the emerging market countries expressed as a ratio to GDP in those countries.

5/ Three-month LIBOR rate.

6/ Refers to four-quarter (t/t-4) change in primary balance.

7/ Policy rate differential with the three-month LIBOR rate, adjusted for the difference between the country's inflation and U.S. inflation.

8/ As classified under the eight-category scale of the IMF's Annual Report on Exchange Rate Arrangements and Exchange Restrictions, a higher score indicates a more flexible exchange rate regime.

9/ Fitted cumulative sum of disbursed IMF financing (in percent of GDP) starting with four quarters preceding the crisis, interacting with an IMF program dummy. Fitted values were generated by a Tobit model with the following regressors: time in crisis (log), IMF country quota, lagged of IKAC values (two quarters), real GDP growth, lagged levels of debt/GDP, ST debt/FX reserves, and CAB/GDP. 
believe that changes in the exchange rate regime and IMF financing may indeed be important determinants of crisis duration, and to provide a further check for the robustness of our results, we present the models with time dependency that include these variables (regressions 2a and 3a).

With the exceptions highlighted above, the empirical findings are generally robust to alternative model specifications, yielding very similar parameter estimates and significance levels. The explanatory power of all models is reasonably good and diagnostic results for the logistic and linear time-dependency specifications provide additional comfort with respect to the model fit (Box 1). ${ }^{20}$ Overall, the logistic time specification provides the tightest fit to our data, as witnessed by the highest likelihood value. ${ }^{21}$

The estimates show that initial and external conditions are key in determining the duration of a crisis. ${ }^{22}$

- In all regressions, the relative size of the pre-crisis current account deficit-thus the extent of the initial external disequilibrium — is shown to be an important determinant. Larger deficits are associated with longer crises, possibly reflecting spillover effects of wrenching current account adjustment. Similarly, higher levels of external debt and, in the model without time dependency, short-term external debt, are strongly correlated with longer crises.

- $\quad$ Benign global liquidity conditions as measured by the world interest rate- the three-month LIBOR rate-and favorable developments in partner countries' demand for domestic exports are found to shorten significantly the duration of a crisis. However, investors' attitude toward risk in emerging markets-as measured by overall net capital flows to these markets - is only weakly associated with the probability of exiting from a crisis. In fact, the variable drops out of the specification without time dependency, indicating limited robustness.

The econometric results also suggest that the authorities' policy response has considerable bearing on the probability of exiting a crisis.

- $\quad$ Fiscal policy tightening (with a one-quarter lag) is found to shorten crisis duration in all model specifications, likely reflecting signaling and confidence effects. This

\footnotetext{
${ }^{20}$ While it is technically difficult to use similar diagnostic tools for the model with no time variable without making arbitrary assumptions on the disbursement profile of IMF financing, the comparable likelihood value for this model also indicates significant explanatory power.

${ }^{21}$ This specification has the lowest Bayesian and Akaike information criteria, suggesting that it strikes the best balance between parsimony and performance among the three alternative specifications.

${ }^{22}$ Given that the dependent variable in the model is a binary indicator of the end of a crisis, a positive coefficient in the estimated regressions associates higher values of an explanatory variable with a greater probability of exiting from crisis.
} 


\section{Box 1. Some Further Diagnostic Results}

To obtain better insight into the estimated models and evaluate the different specifications, we perform a series of diagnostic experiments (Box Figure 1).

- $\quad$ The explanatory power of the model is reasonably good. This is revealed by comparing the probability of exiting from a crisis (known in the literature as the hazard rate) predicted by our baseline model with that derived from the Nelson-Aalen estimator of cumulative hazard, an estimator that is based exclusively on the distribution of the 18 observed durations of crises (see Figure 1 in the main text). The fact that the two probability curves are quite similar provides comfort with respect to the model specification and its explanatory power.

- $\quad$ The time-varying explanatory variables specified in the model are critical in determining the probability of exiting from a crisis. This is made clear by setting the explanatory variables (e.g., initial and external conditions, policy response variables, and IMF financial support) to zero in the baseline model. This experiment results in a dramatic shift in the probability curve to the upper left, far away from the NelsonAalen hazard. Along the same lines, a simple duration model—estimated under the assumption that the probability of exit is influenced exclusively by the time spent in crisis—produces a virtually flat probability curve (broken line), which is inconsistent with evidence from the data.

- $\quad$ The logistic specification for the time dependence component provides the best fit. While the specification of time dependence (logistic versus linear) in the baseline hazard makes little difference for the estimated parameter values, there seems to be some difference in terms of the model's predictive power. The specification based on the logistic formulation appears to be somewhat better in predicting the probability of exiting from crises for durations less than 12 quarters. Thus, it would be the preferred specification for 16 out of 18 crises in our sample. The linear specification provides a better fit for longer crises.

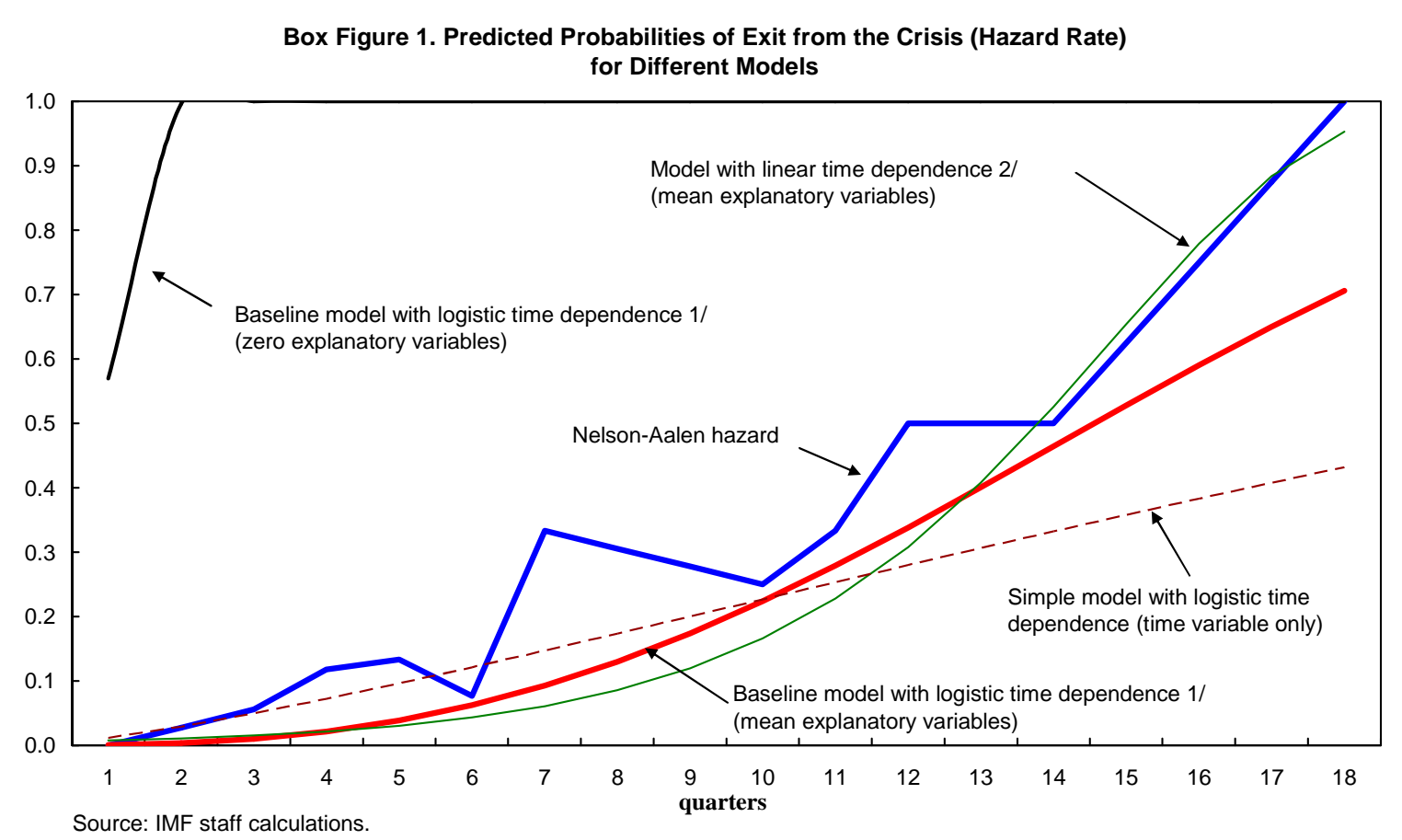

1/ Refers to regression (2a) reported in Table 4. 2/ Refers to regression (3a) reported in Table 4. 
finding seems to suggest that the confidence building effects of fiscal consolidation dominate any concretionary impact.

- $\quad$ For monetary policy, there is some evidence that stemming capital outflows by raising real interest rates (relative to rates elsewhere in the world) shortens crisis duration, but with a lag of three quarters. This said, the negative (albeit insignificant in some model specifications) coefficient on the real interest rate differential with a two-quarter lag implies that the overall estimated effect of monetary tightening may not be clear cut.

- $\quad$ The exchange rate regime variable enters the regressions with a negative sign, implying that a shift toward a more flexible exchange rate in the midst of a crisis tends to prolong the crisis. While floating the exchange rate helps to reduce external imbalances, a deterioration in public and private sector balance sheets appears to outweigh this positive effect. ${ }^{23}$ Although the depletion of foreign reserves amid intense market pressures often leave policymakers little choice, floating the exchange rate in the midst of a crisis may indeed result in sharp overshooting, and wreak havoc in sectoral balance sheets, thereby deepening the crisis.

In all specifications, the positive sign of the coefficient of IMF financial support implies that the probability of exiting from a crisis increases with larger (cumulative) financing packages. However, this result is not sufficiently robust across different specifications, being statistically significant only in the time-invariant specification for the baseline hazard.

\section{B. Counterfactual Experiments}

To gain further insights into the relative importance of the factors influencing the persistence of crises, some counterfactual experiments are performed. The experiments are based on the augmented model with the logistic time specification (regression (2a) in Table 2), which exhibits the best overall fit.

- $\quad$ First, the estimated parameters and the mean values of the model variables are used to construct the baseline predicted probability of exiting from crisis (Figure 4).

- $\quad$ Second, the impact of changes in individual variables on the predicted probability of exiting from crisis and its estimated duration is computed. Specifically, the mean value of individual explanatory variables is changed by one standard deviation (Table 3). The resulting difference between the baseline probability and the probability arising from the counterfactual experiment can be used to assess the relative importance of different factors. In Figure 4, for illustration, this difference is

\footnotetext{
${ }^{23}$ This result seems to confirm the findings of other studies (see Eichengreen et al (1998)) according to which the chances of a smooth transition to greater exchange rate flexibility are generally not good in a crisis. Indeed, our findings show that the level of a country's external debt-which is highly sensitive to exchange rate dynamics - is a critical factor influencing the probability of exiting from a crisis.
} 
evaluated (vertically) at the median crisis duration of seven quarters. Alternatively, the potential impact on expected crisis duration can be gauged (horizontally) by comparing the number of quarters in crisis passed before the predicted probability of exiting from crisis reaches a certain value (one-half in the figure).

An important point to note, is that the factors that seem to have the strongest influence on crisis duration - initial and external conditions - are those outside the control of the policymakers by the time a crisis erupts. The largest gain in shortening the expected duration of capital account crises - by roughly 2-3 quarters, or about 30-40 percent of the median duration - is associated with either stronger initial conditions (lower pre-crisis current account deficits and relatively moderate external debt burden) or with a more benign external environment (more favorable international liquidity conditions and buoyant trade partners' demand).

Table 3. Descriptive Statistics for the Model's Explanatory Variables

\begin{tabular}{lrrr}
\hline & N & Mean & $\begin{array}{r}\text { Standard } \\
\text { deviation }\end{array}$ \\
\hline Exchange rate regime 1/ & 153 & 6.67 & 2.02 \\
Real interest rate differential (lag 2) 2/ & 153 & 6.27 & 43.41 \\
Real interest rate differential (lag 3) 2/ & 153 & 6.12 & 40.34 \\
Change in primary balance (lag 1) 3/ 4/ & 153 & 0.48 & 4.76 \\
Capital flows to EM countries 5/ & 153 & 1.41 & 0.89 \\
Three-month Libor rate & 153 & 4.54 & 1.84 \\
Trade-weighted domestic demand (change) & 153 & 0.58 & 0.62 \\
External debt (lag 1) 3/ & 153 & 70.04 & 28.92 \\
Current account balance (pre-crisis) 3/ & 18 & -2.45 & 3.89 \\
Cumulative IMF financing 6/ & 15 & 12.96 & 13.75 \\
\hline
\end{tabular}

Source: IMF staff calculations.

1/ As in IMF's "Annual Report on Exchange Rate Arrangements and Exchange Restrictions."

2/ Policy rate differential with the three-month Libor rate, adjusted for the difference between the country's inflation and U.S. inflation.

$3 /$ In percent of GDP.

4/ Refers to four-quarter (t/t-4) change in primary balance.

$5 /$ Total net private capital flows to emerging market countries (ratio to GDP).

6/ Cumulative sum of disbursed IMF financing (in percent of quarterly GDP), starting with four quarters preceding the crisis. 
Figure 4. Predicted Probabilities of Exit from the Crisis under Different Scenarios

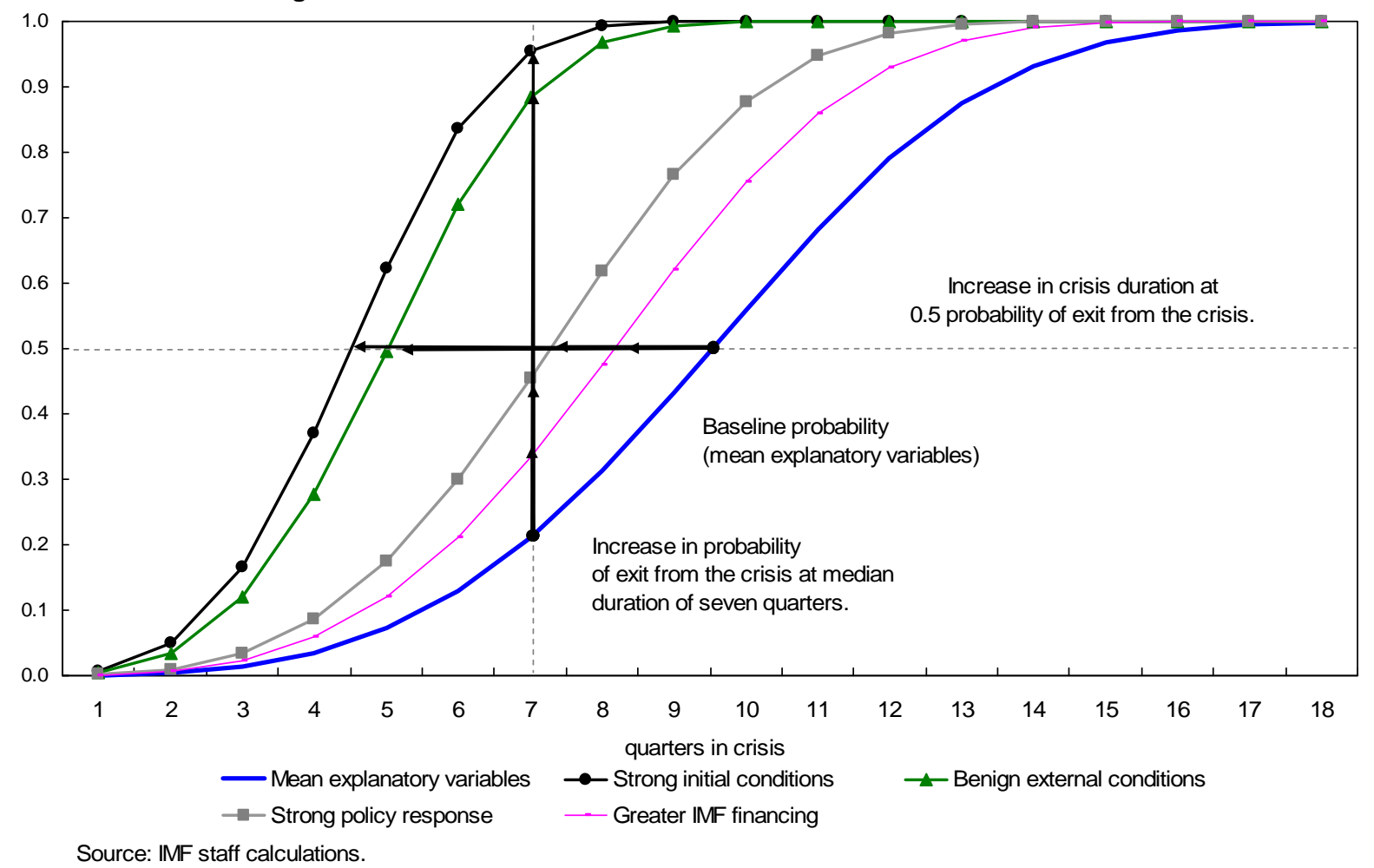

Stronger initial conditions result from consistent implementation of sound macroeconomic policies. Therefore, these empirical findings underscore the critical importance of sustained prudent policies and crisis prevention efforts aimed at strengthening a country's fundamentals in normal times (the "good policies" factor). But the results also highlight the importance of the "good luck" factor, in terms of favorable external conditions.

Further counterfactual experiments were performed to assess the importance of each explanatory variable (Figures 5 and 6). The results also confirm that a strong policy response-such as undertaking fiscal adjustment, avoiding large exchange rate devaluations in the midst of the crisis, and (to a lesser extent) raising interest rates-increases the probability of exiting from a crisis. Indeed, a stronger improvement in the primary fiscal balance (by one standard deviation) or the possibility to maintain the pre-crisis exchange rate regime is found to increase the probability of exiting from a crisis by about 10 percent or, equivalently, shorten crisis duration by about one quarter. A one standard deviation higher real interest rate differential is predicted to raise the probability of exiting from crisis marginally by 3 percent, and to shorten duration by about 0.4 quarters.

The marginal impact of one standard deviation higher IMF financing would seem to increase the probability of exiting from a crisis by about 12 percent but this result is based on a 
Figure 5. Increase in Predicted Probability of Exit from Crisis under Various Scenarios 1/

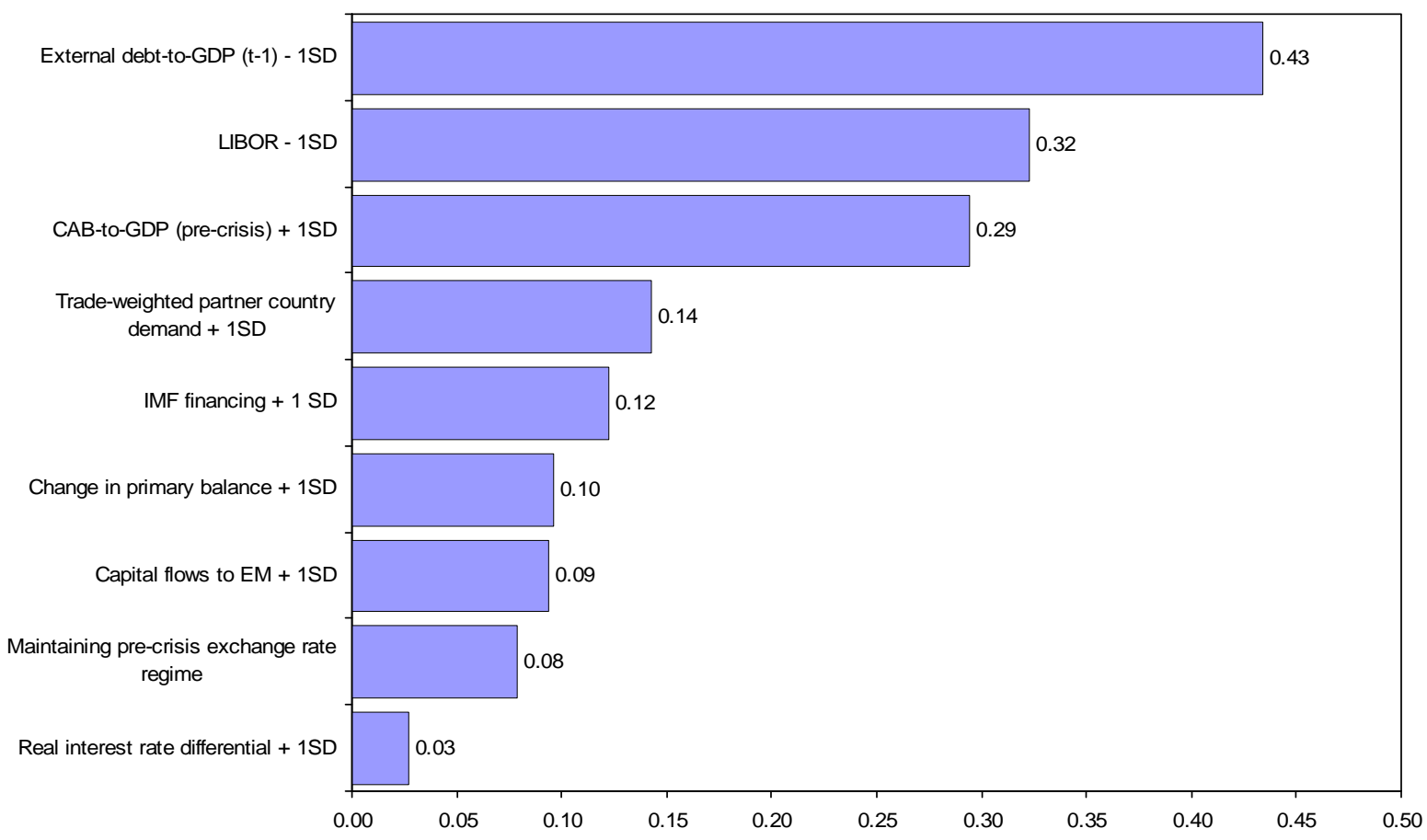

Source: IMF staff calculations.

$1 /$ Evaluated at median crisis duration of seven quarters. Unless noted otherwise, the mean value of individual explanatory variables is changed by one standard deviation (SD).

Figure 6. Reduction in Predicted Crisis Duration under Various Scenarios 1/

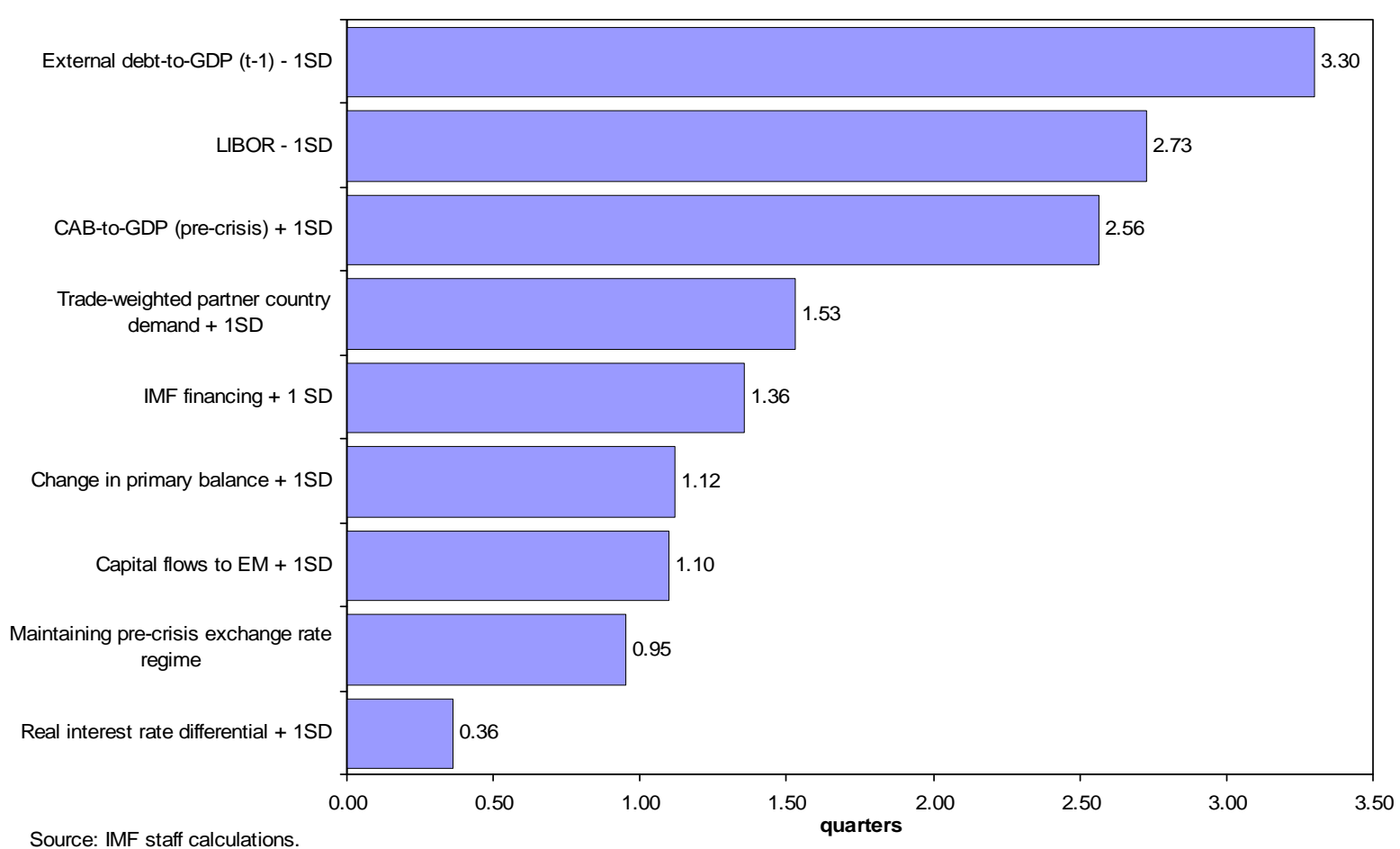

$1 /$ Evaluated at 0.5 probability of staying in crisis. Unless noted otherwise, the mean value of individual explanatory variables is changed by one standard deviation (SD). 
regression coefficient which is not statistically significant. ${ }^{24}$ These findings however need to be interpreted with caution because it is difficult to separate the impact of Fund financing from the effects of a Fund-supported program on a country's policy response variables.

\section{CONCLUSIONS}

This study contributes to the literature on capital account crises in two ways. First, our analysis of the sample of crisis episodes between 1994 and 2002 establishes a clear relationship between the persistence of crises, their complexity, and the intensity of movement of key macroeconomic variables. Second, it provides a systematic examination of the determinants of the probability of exit from crisis to shed light on the relative importance of the various factors affecting crisis duration.

Our econometric analysis suggests that initial conditions and the external environment are key explanatory variables for crisis duration. This result highlights the importance of consistently prudent macroeconomic policies, which determine initial conditions at a time of financial distress. By the same token, it underscores the role of factors-initial and external conditions-largely outside the control of the authorities once a crisis occurs.

The policy response to a crisis is also found to influence its duration. This is particularly evident for appropriate fiscal adjustment, which can shorten duration significantly. While the evidence for monetary policy is more mixed, our results suggest that an increase in (real) interest rates may also help to shorten a crisis. Changes in the exchange rate regime during a crisis, often resulting in sharp currency depreciations, tend to be associated with longer crises, likely reflecting adverse balance sheet effects. This said, we need to recognize that the strong market pressures during crises severely limit actual policy options.

In all, the results confirm a strong link between complexity of a capital account crisis and its duration. They also suggest that good policies matter, but in a hard way for policy making, since it is too late to correct initial conditions once a crisis has erupted. At that difficult stage, countries are hostage of their past. This underscores the importance of crisis prevention efforts.

\footnotetext{
24 The impact of IMF support is statistically significant in the model with no time dependence (regression (4) in Table 4), where the corresponding parameter was estimated more accurately.
} 


\section{APPENDIX I: Measuring the Duration of Capital Account Crises}

Measuring the duration of a crisis requires the identification of its beginning and end. While there are established methods to identify the start of capital account crises, timing the end of a crisis is more complicated. ${ }^{25}$ At the beginning of a crisis, key indicators (such as spreads on sovereign bonds, international reserves, and the exchange rate) tend to move sharply and in a highly correlated fashion. In contrast, at the tail end of a crisis, these indicators often do not move together and may even give conflicting signals. To overcome this problem, we employ a hybrid approach—originally developed in Mecagni et al (2007)—-that combines the information of several indicators to measure the duration of crises. Specifically, to measure duration of a crisis, we construct an Index of Capital Account Crises (IKAC) that associates crises with the following conceptual aspects:

- $\quad$ Escalation of pressure indicators. Sudden strong pressure on the exchange rate, reserves, and spreads typically marks the beginning of financial distress. Similarly, when such pressure subsides, and these variables stabilize, this can be an indicator of the end of a crisis.

- $\quad$ Capital outflows. A sudden stop or an abrupt outflow of capital is the defining characteristic of a capital account crisis. In the same vein, the resumption of capital inflows is another signal that the end of a crisis has been reached.

- Deviation of spreads from "normal” levels. A measure of investor sentiment generally available on a continuous basis is the secondary market spread on sovereign bonds. Since a sharp increase in spreads is closely associated with financial distress, a return to "normal" values could be further a signal that the crisis is over.

The index is constructed on the basis of quarterly data on foreign exchange reserves (FX), the nominal effective exchange rate (NEER), secondary market spreads on sovereign bonds (S), and net private capital flows scaled as a ratio to GDP (K):

$$
I K A C_{i, t}=-\left(F X_{i, t}-F X_{i, t}^{\text {trend }}\right)-\ln \left(N E E R_{i, t} / N E E R_{i, t-1}\right)+S_{i, t}-K_{i, t}
$$

Each of the four terms included in the index is standardized-that is, its mean is set equal to zero and its standard deviation equal to one. The variables enter the index so that positive values denote financial pressure, capturing deviations from "normal levels" of the various components. In particular, the index associates the end of a crisis episode with spreads and capital flows (both in levels) returning to the country-specific sample mean, and with foreign exchange reserves approaching their long-run trend. The nominal effective exchange rate enters the index in percentage changes, thereby relating the stabilization of the exchange rate to the end of the crisis.

\footnotetext{
${ }^{25}$ The literature on crisis identification has typically focused on the beginning of crises, with little systematic attention to their end.
} 
Our measure of crisis duration is based on the IKAC index. The start of a crisis is identified as the first of two consecutive quarters in which the value of the index is positive. ${ }^{26}$ The zero threshold yields starting dates that broadly agree with the assessments in IMF staff documents (Appendix Tables 1 and 2). Symmetrically, the end of a crisis is identified as the first of two consecutive quarters in which the value of the index is negative. The application of the index methodology to data for the 12 emerging market economies recognized as having experienced capital account crises yields 18 crisis episodes.

Crisis duration varies quite widely across crisis episodes. This likely reflects differences in underlying vulnerabilities, external environment, and policy response. The estimated crisis duration ranges from three quarters in the 1998 Turkey crisis episode to 18 quarters in the 1997 Thailand crisis (Appendix Figure 1). The average and median duration of a capital account crisis are about $8 \frac{1}{2}$ quarters and seven quarters, respectively, with 16 out of 18 crises in the sample lasting less than 12 quarters (Appendix Tables 1 and 2).

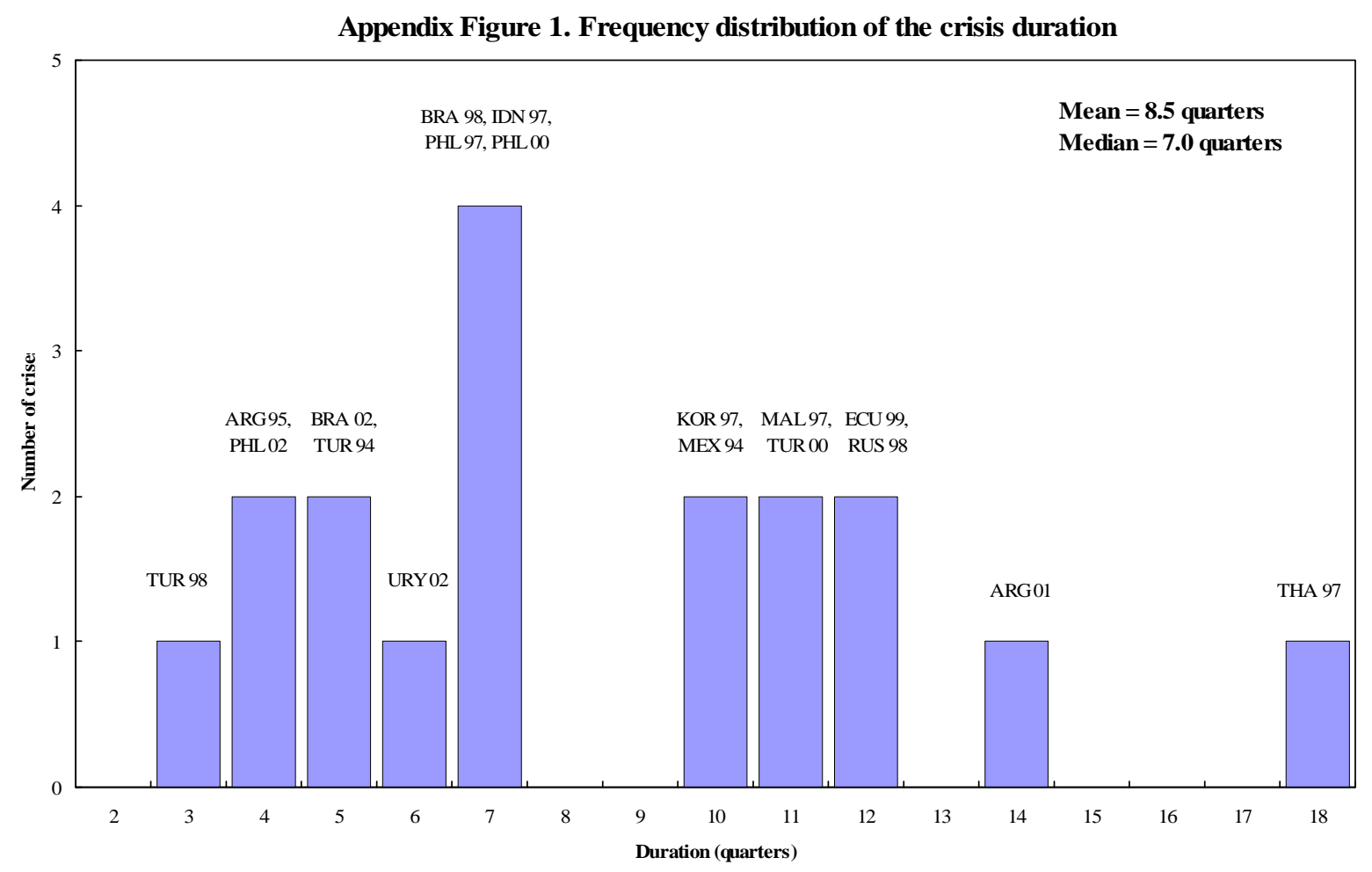

${ }^{26}$ The mean of the index is zero by construction, since each component of the index has zero mean. 
Appendix Table 1: Timeline of Recent Capital Account Crises

\begin{tabular}{|c|c|c|c|c|c|c|c|c|c|c|}
\hline \multirow[t]{2}{*}{ Country } & \multirow{2}{*}{ Crisis beginning $1 /$} & \multicolumn{9}{|c|}{ Crisis end $2 l$} \\
\hline & & Index 3 I & $\begin{array}{r}\text { Capital } \\
\text { outflow } 4 /\end{array}$ & Spreads 5 I & Reserves 6 I & $\begin{array}{r}\text { Exchange } \\
\text { rate } 71\end{array}$ & $\begin{array}{r}\text { Market } \\
\text { access } 8 I\end{array}$ & $\begin{array}{l}\text { Exceptional financing } \\
\text { (excluding IMF) } 9 /\end{array}$ & $\begin{array}{r}\text { IMF } \\
\text { financing } 10 /\end{array}$ & $\begin{array}{r}\text { IMF staff } \\
\text { assessment 11/ }\end{array}$ \\
\hline Argentina & Q1, 1995 & Q4, 1995 & Q3, 1995 & Q1, 1996 & Q4, 1995 & Q3, 1995 & Q3, 1995 & Q2, 1996 & Q4, 1997 & Q4, 1995 - Q1, 1996 \\
\hline Argentina & Q3, 2001 & Q4, 2004 & Q2, 2004 & not returned & not returned & Q4, 2002 & Q1, 2005/Q2, 2005 & ongoing & Q2, 2004 & Q4, 2003 - Q1, 2004 \\
\hline Brazil & Q3, 1998 & Q1, 2000 & Q2, 1999 & Q1, 1999 & not returned & Q1, 2000 & Q2, 1999 & Q3, 1999 & Q1, 2000 & Q2, 1999 - Q3, 1999 \\
\hline Brazil & Q2, 2002 & Q2, 2003 & Q1, 2004 & Q4, 2003 & Q1, 2003 & Q1, 2003 & Q2, 2003 & no exc. fin. & Q4, 2003 & Q3, 2003 - Q4, 2003 \\
\hline Ecuador & Q1, 1999 & Q4, 2001 & Q4, 2000 & Q4, 2003 & not returned & Q2, 2000 & Q3, 2000/Q4, 2005 & ongoing & Q4, 2003 & Q4, 2000 - Q1, 2001 \\
\hline Indonesia & Q4, 1997 & Q2, 1999 & Q4, 1998 & Q4, 1998 & Q4, 1998 & Q2, 1999 & Q1, 2004 & no exc. fin. & Q1, 2004 & Q4, 1998 - Q2, 1999 \\
\hline Korea & Q4, 1997 & Q1, 2000 & Q1, 1999 & Q1, 1998 & Q2, 1998 & Q2, 1998 & Q2, 2003 & no exc. fin. & Q3, 1999 & Q4, 1998 - Q1, 1999 \\
\hline Malaysia & Q3, 1997 & Q1, 2000 & Q2, 1998 & Q3, 1998 & Q1, 1999 & Q4, 1998 & Q2, 1999 & no exc. fin. & no program & Q2, 1999 - Q4, 1999 \\
\hline Mexico & Q4, 1994 & Q1, 1997 & Q3, 1996 & Q1, 1997 & Q3, 1997 & Q1, 1997 & Q3, 1995/Q3, 1995 & Q1, 1998 & Q1, 1996 & Q4, 1995 - Q2, 1996 \\
\hline Philippines & Q3, 1997 & Q1, 1999 & Q2, 1999 & Q2, 1998 & Q1, 1999 & Q4, 1998 & Q2, 1998 & ongoing & Q4, 1999 & Q1, 1999 - Q2, 1999 \\
\hline Philippines & Q2, 2000 & Q4, 2001 & Q2, 2001 & not returned & Q4, 2001 & Q4, 2001 & Q2, 2001 & ongoing & Q4, 2000 & Q1, 2001 - Q2, 2001 \\
\hline Philippines & Q3, 2002 & Q2, 2003 & Q2, 2003 & not returned & not returned & Q2, 2004 & no access loss & ongoing & no program & Q1, 2003 - Q2, 2003 \\
\hline Russia & Q3, 1998 & Q2, 2001 & Q2, 1999 & Q2, 2001 & Q2, 2000 & Q2, 1999 & Q1, 2000/Q3, 2000 & Q1, 2003 & Q4, 1999 & Q2, 1999 - Q3, 1999 \\
\hline Thailand & Q3, 1997 & Q4, 2001 & Q1, 2001 & Q1, 1998 & Q3, 2002 & Q2, 1998 & Q4, 2001 & Q3, 2002 & Q3, 1999 & Q1, 2001 - Q2, 2001 \\
\hline Turkey & Q1, 1994 & Q1, 1995 & Q3, 1994 & $\ldots$ & Q3, 1994 & $\ldots$ & Q2, 1995 & no exc. fin. & Q4, 1995 & Q1, 1995 - Q2, 1995 \\
\hline Turkey & Q3, 1998 & Q1, 1999 & Q1, 1999 & Q3, 1998 & Q3, 1999 & Q4, 1999 & no access loss & no exc. fin. & no program & Q4, 1998 \\
\hline Turkey & Q4, 2000 & Q2, 2003 & Q4, 2002 & Q4, 2003 & Q3, 2002 & Q2, 2003 & no access loss & Q1, 2001 & ongoing & Q2, 2003 - Q3, 2003 \\
\hline Uruguay & Q2, 2002 & Q3, 2003 & Q4, 2002 & not returned & not returned & Q2, 2004 & Q2, 2003/Q4, 2003 & ongoing & Q3, 2006 & Q3, 2003 - Q4, 2003 \\
\hline
\end{tabular}

Source: IMF staff calculations and assessments.

$1 /$ First crisis quarter as determined by the index.

2/ Exit quarter from the crisis.

3/ Based on a combined index (IKAC) of capital flows, spreads, reserves, and nominal effective exchange rate.

$4 /$ Corresponds to the first quarter in which standardized capital outflows are nonnegative.

5/ Corresponds to the first quarter in which the risk premium over EMBIG returns to within 50 bps of the four-quarter average before the crisis. For Argentina (1995) and Mexico (1994), this criterion is applied to the

country spreads rather than risk premium due to data availability.

6/ Corresponds to the first quarter in which reserves (net of IMF) return to the four-quarter average before the crisis.

$7 /$ Corresponds to the first quarter of the period with two consecutive quarters recording nonnegative percentage changes in NEER.

$8 /$ Corresponds to the quarter of the first primary issuance of international government bonds after the beginning of the crisis. In cases with two dates, the first date corresponds to issuance associated with debt restructuring.

9/ Corresponds to the first quarter of a period of four consecutive quarters in which gross exceptional financing (sum of debt rescheduling and arrears) falls below 0.25 percent of GDP. The term "ongoing" reflects reliance on

exceptional financing at the end of the sample considered $(Q 4,2004)$.

$10 /$ Corresponds to the first quarter of the period with four consecutive quarters without IMF disbursements.

$11 /$ The dates of the end of a crisis are inferred from the analysis of Fund staff documents. 
Appendix Table 2: Duration of Recent Capital Account Crises

\begin{tabular}{|c|c|c|c|c|c|c|c|c|c|c|}
\hline \multirow[t]{2}{*}{ Country } & \multirow[t]{2}{*}{ Crisis beginning $1 /$} & \multicolumn{9}{|c|}{ Crisis end $2 /$} \\
\hline & & Index $3 \mid$ & $\begin{array}{r}\text { Capital } \\
\text { outflow } 4 /\end{array}$ & Spreads 5l & Reserves 6/ & $\begin{array}{r}\text { Exchange } \\
\text { rate } 71\end{array}$ & $\begin{array}{r}\text { Market } \\
\text { access 8I }\end{array}$ & $\begin{array}{r}\text { Exceptional financing } \\
\text { (excluding IMF) } 9 /\end{array}$ & $\begin{array}{r}\text { IMF } \\
\text { financing } 10 /\end{array}$ & $\begin{array}{r}\text { Staff } \\
\text { assessment 11/ }\end{array}$ \\
\hline Argentina & Q1, 1995 & 4 & 3 & 5 & 4 & 3 & 3 & 6 & 12 & $4-5$ \\
\hline Argentina & Q3, 2001 & 14 & 12 & not returned & not returned & 6 & 16 & ongoing & 12 & $10-11$ \\
\hline Brazil & Q3, 1998 & 7 & 4 & 3 & not returned & 7 & 4 & 5 & 7 & $4-5$ \\
\hline Brazil & Q2, 2002 & 5 & 8 & 7 & 4 & 4 & 5 & no exc. fin. & 7 & $6-7$ \\
\hline Ecuador & Q1, 1999 & 12 & 8 & 20 & not returned & 6 & 28 & ongoing & 20 & $8-9$ \\
\hline Indonesia & Q4, 1997 & 7 & 5 & 5 & 5 & 7 & 26 & no exc. fin. & 26 & $5-7$ \\
\hline Korea & Q4, 1997 & 10 & 6 & 2 & 3 & 3 & 23 & no exc. fin. & 8 & $5-6$ \\
\hline Malaysia & Q3, 1997 & 11 & 4 & 5 & 7 & 6 & 8 & no exc. fin. & no program & $8-10$ \\
\hline Mexico & Q4, 1994 & 10 & 8 & 10 & 12 & 10 & 4 & 14 & 6 & $5-7$ \\
\hline Philippines & Q4, 1997 & 7 & 8 & 4 & 7 & 6 & 4 & ongoing & 10 & $7-8$ \\
\hline Philippines & Q2, 2000 & 7 & 5 & not returned & 7 & 7 & 5 & ongoing & 3 & $4-5$ \\
\hline Philippines & Q3, 2002 & 4 & 4 & not returned & not returned & 8 & no access loss & ongoing & no program & $3-4$ \\
\hline Russia & Q3, 1998 & 12 & 4 & 12 & 8 & 4 & 9 & 19 & 6 & $4-5$ \\
\hline Thailand & Q3, 1997 & 18 & 11 & 3 & 21 & 4 & 18 & 21 & 9 & $15-16$ \\
\hline Turkey & Q1, 1994 & 5 & 3 & $\ldots$ & 3 & $\ldots$ & 6 & no exc. fin. & 8 & $5-6$ \\
\hline Turkey & Q3, 1998 & 3 & 3 & 0 & 5 & 6 & no access loss & no exc. fin. & no program & 2 \\
\hline Turkey & Q4, 2000 & 11 & 9 & 13 & 8 & 11 & no access loss & 2 & ongoing & $11-12$ \\
\hline Uruguay & Q2, 2002 & 6 & 3 & not returned & not returned & 9 & 7 & ongoing & 18 & $6-7$ \\
\hline Mean: & & 8.5 & 6.0 & 6.8 & 7.2 & 6.3 & 11.1 & 11.2 & 10.9 & $6.2-7.3$ \\
\hline Median: & & 7.0 & 5.0 & 5.0 & 7.0 & 6.0 & 7.0 & 10.0 & 8.5 & $5.0-7.0$ \\
\hline
\end{tabular}

Source: IMF staff calculations and assessments.

$1 /$ First crisis quarter as determined by the index

2/ Includes exit quarter from the crisis. Means and medians are computed exclusively over the samples of crises with well-defined durations.

3/ Based on a combined index (IKAC) of capital flows, spreads, reserves, and nominal effective exchange rate.

$4 /$ Corresponds to the first quarter in which standardized capital outflows are nonnegative.

5/ Corresponds to the first quarter in which the risk premium over EMBIG returns to within 50 bps of the four-quarter average before the crisis. For Argentina (1995) and Mexico (1994), this criterion is applied to the

country spreads rather than risk premium due to data availability.

$6 /$ Corresponds to the first quarter in which reserves (net of IMF) return to the four-quarter average before the crisis.

$7 /$ Corresponds to the first quarter of the period with two consecutive quarters recording nonnegative percentage changes in NEER

$8 /$ Corresponds to the quarter of the first primary issuance of international government bonds after the beginning of the crisis, excluding issues associated with debt rescheduling.

9/ Corresponds to the first quarter of a period of four consecutive quarters in which gross exceptional financing (sum of debt rescheduling and arrears) falls below 0.25 percent of GDP. The term "ongoing” indicates

reliance on exceptional financing at the end of the sample considered (Q4, 2004).

$10 /$ Corresponds to the first quarter of the period with four consecutive quarters without IMF disbursements.

$11 /$ Refers to the dates of the end of a crisis that are inferred from the analysis of Fund staff documents. 


\section{APPENDIX II: A Model for the Duration of Capital Account Crises}

The paper applies survival analysis to identify factors influencing the duration of capital account crises. More specifically, it investigates how various covariates-including initial conditions of the economy, the external environment, policy responses, and the extent of IMF financial involvement—affect the "survival” time of a country in a capital account crisis.

Let $T \geq 0$ denote the time at which an economy exits from a capital account crisis, and $t$ denote a particular value of $T$. The survivor function - the probability of a country "surviving" (i.e., remaining) in crisis mode after time $t$-is defined as

$S(t) \equiv 1-F(t)=P(T>t)$,

where $F(t)=P(T \leq t)$ is the cumulative distribution function of $T$.

Taking into consideration discreteness in observed crisis durations, the conditional hazard function at time $t$ is defined as the probability of a country leaving the crisis mode in the interval $[t, t+h]$, given being in crisis up until time $t$ and conditional on values of timevariant explanatory variables summarized by vector $X$ :

$$
\lambda[t ; X(t)]=\lim _{h \downarrow 0} \frac{P[t \leq T<t+h \mid T \geq t, X(t+h)]}{h}
$$

Following the survival analysis literature, the model assumes a proportional hazard with time-varying covariates of the following form:

$$
\lambda[t ; X(t)]=\kappa[X(t)] \lambda_{0}(t)
$$

where $\kappa($.$) is a nonnegative function of X$ and $\lambda_{0}(t)$ is the baseline hazard. The baseline hazard is common to all countries in crisis while the individual hazard functions differ proportionately based on a function $\kappa($.) of observed covariates.

The complementary log-log model used in this paper assumes that the discrete hazard rate has the following specification:

$$
p[t, X(t) \mid \beta, u]=1-\exp \left[-\exp \left(\lambda_{0}(t)+X \beta+u\right)\right]
$$

where the baseline hazard function is assumed to be, for example, of the form $\lambda_{0}(t)=\log (t)$ and $X \beta$ includes an intercept term. The "error" term $u$ is a random variable, summarizing the impact of omitted variables on the hazard rate. ${ }^{27}$ Since it is possible that conditioning on observed covariates may be insufficient to capture all heterogeneity in various crisis episodes, it is important to test for unobserved heterogeneity in the sample of capital account

\footnotetext{
${ }^{27}$ An alternative interpretation of this term is that it captures measurement errors in recorded regressors or recorded survival times.
} 
crisis episodes. To this end, the error term in the hazard function (AII.4) for different crises can be assumed to be drawn from a distribution with parameters that can be estimated (i.e., Normal, Gamma, or Inverse Gaussian distributions). The key assumption used in models with unobserved heterogeneity is that the heterogeneity is independent of the observed covariates. The probabilities defined in (AII.4) are used to construct a likelihood function, and the parameters of the model are estimated by maximizing the log-likelihood. 


\section{REFERENCES}

Calvo, G. A., 1998, "Capital Flows and Capital-Market Crises: The Simple Economics of Sudden Stops,” Journal of Applied Economics, Vol. 1, No. 1, pp. 35-54.

Calvo, G. A., 2005, “Crises in Emerging Market Economies-A Global Perspective,” NBER Working Paper No. 11305.

Calvo, G. A., A. Izquierdo, and L. F. Mejia, 2004, “On Empirics of Sudden Stops: The Relevance of Balance-Sheet Effects,” NBER Working Paper No. 10520.

Calvo, G., A. Izquierdo, and E. Talvi, 2006, "Phoenix Miracles in Emerging Markets: Recovering without Credit from Systemic Financial Crises," NBER Working Paper No. 12101.

Caprio, G. and D. Klingebiel, 2003, "Episodes of Systemic and Borderline Financial Crises,” unpublished draft, World Bank: Washington DC.

Demirguc-Kunt, A. and E. Detragiache, 2005, Cross-Country Empirical Studies of Systemic Bank Distress: A Survey, IMF Working Paper/05/96.

Edwards, S., 2005, “Capital Controls, Sudden Stops and Current Account Reversals,” NBER Working Paper No. 11170.

Eichengreen, B., P. Gupta, and A. Mody, 2006, "Sudden Stops and IMF-Supported Programs,” IMF Working Paper, WP/06/101.

Eichengreen, B., P. Mason, H. Bredenkamp, B. Johnston, J. Hamann, E. Jadresic, I. Ötker, 1998, “Exit Strategies: Policy Options for Countries Seeking Greater Exchange Rate Flexibility,” IMF Occasional Paper No. 168.

Frankel, J. and E. A. Cavallo. 2004, "Does Openness to Trade Make Countries More Vulnerable to Sudden Stops, Or Less? Using Gravity to Establish Causality,” NBER Working Paper No. 10957.

Ghosh, A., 2006, “Capital Account Crises: Lessons for Crisis Prevention,” paper prepared for the High-Level Seminar on Crisis Prevention, Singapore, July 10-11, 2006.

Hutchison, M. and I. Noy, 2004, "Sudden Stops and the Mexican Wave: Currency Crises, Capital Flow Reversals and Output Loss in Emerging Markets,” Department of Economics, UCSC Paper 573.

Kaminsky, G., 2003, “Varieties of Currency Crises,” NBER Working Paper No. 10193. 
Kaminsky, G. and C. Reinhart, 1999, “The Twin Crises: The Causes of Banking and Balance-of-Payments Problems,” American Economic Review, Vol. 89, No.3, pp.473-500.

Krugman, P., “Crises: The Next Generation?,” paper prepared for the Razin conference, Tel Aviv University, March 25/26, 2001.

Manasse, P., Chamon, M. and A. Prati, 2006, "Can We Predict the Next Capital Account Crisis?” presented at the $7^{\text {th }}$ Jacques Polak Annual Research Conference, Washington, D.C., November 9-10, 2006.

Mecagni, M., R. Atoyan, D. Hofman, and D. Tzanninis, 2007, “The Duration of Capital Account Crises_An Empirical Analysis,” IMF Working Paper, WP/07/258.

Ramakrishnan, U., and J. Zalduendo, 2006, “The Role of IMF Support in Crisis Prevention,” IMF Working Paper, WP/06/75.

Roubini, N. and B. Setser, 2004, Bailouts or Bail-ins? Responding to Financial Crises in Emerging Economies, Institute for International Economics: Washington, D 